Counsellia: Jurnal Bimbingan dan Konseling

Volume 11 (1) 86 - 94 Mei 2021

ISSN: 2088-3072 (Print) / 2477-5886 (Online)

DOI: $10.25273 /$ counsellia.v11i18393

Available online at: http://e-journal.unipma.ac.id/index.php/JBK

\title{
Cyber Counseling Sebagai Metode Meningkatkan Layanan Bimbingan dan Konseling di Sekolah: Literature Review
}

\author{
Muthia Fanny Fadhilah $^{1} \bowtie$, Dimas Alkindi ${ }^{2}$, Abdul Muhid ${ }^{3}$ \\ ${ }^{1}$ Fakultas Psikologi dan Kesehatan, UIN Sunan Ampel, Surabaya \\ email: $₫$ fannymuthia30@gmail.com \\ ${ }^{2}$ Guru BK Madrasah Tsanawiyah Negeri 03 Sidoarjo \\ email: dimasahong46@gmail.com \\ ${ }^{3}$ Fakultas Psikologi dan Kesehatan, UIN Sunan Ampel, Surabaya \\ email: abdulmuhid@uinsby.ac.id
}

\begin{abstract}
Abstrak
Pengguna internet semakin berkembang pesat karena kemajuan teknologi informasi dan komunikasi. Hampir semua masyarakat di dunia menggunakan internet dalam kehidupan sehari-hari. Semakin berkembangnya teknologi juga berpengaruh terhadap pemberian layanan bimbingan dan konseling terutama di sekolah. Di era globalisasi ini, layanan konseling online atau cyber counseling sangat dibutuhkan para konselor atau guru bimbingan konseling karena dapat memberikan layanan tanpa terbatas jarak dan waktu. Penelitian ini bertujuan untuk membahas mengenai penerapan cyber counseling di sekolah. Penelitian ini menggunakan metode literature review atau studi kepustakaan berupa artikel jurnal. Hasil penelitian diketahui bahwa layanan cyber counseling dinilai efektif karena dapat memberikan kemudahan bagi konselor dan para siswa untuk melakukan konseling yang tidak terbatas jarak dan waktu. Beberapa cara yang digunakan untuk melakukan konseling online, diantaranya yaitu: melalui email, facebook, chat asynchronous, aplikasi riliv, video conference, handphone, dan website. Para guru bimbingan konseling dan konselor diharapkan untuk terus meningkatkan kemampuan dalam menggunakan teknologi informasi dan komunikasi.
\end{abstract}

Kata kunci: Cyber Counseling, Layanan Bimbingan Konseling, Sekolah.

\begin{abstract}
Internet users are growing rapidly due to advances in information and communication technology. Almost all people in the world use the internet in their daily life. The development of technology also affects the provision of guidance and counseling services, especially in schools. In this era of globalization, online counseling services or cyber counseling are very much needed by counselors or counseling teachers because they can provide services without distance and time limitations. This study aims to discuss the application of cyber counseling in schools. This research uses literature review or literature study in the form of journal articles. The results showed that cyber services are not effective because they can provide benefits for counselors and students to conduct counseling that is not limited to distance and time. Several methods are used to conduct online counseling, including: via email, Facebook, asynchronous chat, real applications, video conferencing, cell phones, and websites. Counseling teachers and
\end{abstract}


counselors are expected to continue to improve their ability to use information and communication technology.

Keywords: Cyber Counseling, Counseling Guidance Services, Schools.

\section{Received ; Accepted ; Published}

Citation: Fadhilah F M, dkk. (2021). Cyber Counseling Sebagai Metode Meningkatkan Layanan Bimbingan Dan Konseling di Sekolah: Literature Review. Counsellia: Jurnal Bimbingan dan Konseling, 11(1), 86 - 94. Doi.org/10.25273/counsellia.v11i18393

\section{(c) BY-NC-SA}

Copyright (C2021 Counsellia: Bimbingan dan Konseling

Published by Universitas PGRI Madiun. This work is licensed under the Creative Commons Attribution-NonCommercialShareAlike 4.0 International License

\section{PENDAHULUAN}

Pada tahun 1990 sampai dengan 2000 pengguna internet di seluruh dunia berkembang pesat karena adanya kemajuan teknologi dan komunikasi (Gading, 2020). Hampir seluruh orang di dunia tidak terlepas dari penggunaan internet dalam kehidupan sehari-hari. Penggunaan internet dinilai dapat memberikan kemudahan dalam menjalani aktifitas sehari-hari. Diketahui dari tahun 2005 sampai 2015 jumlah pengguna terus meningkat hingga mencapai 3,5 miliar (Geraijasa, 2019). Sedangkan di tahun 2020 ditemukan sebanyak 4,54 miliar orang menggunakan internet (Chaffey, 2020). Melihat hal tersebut maka dapat dipastikan jumlah pengguna internet tiap tahun akan terus mengalami peningkatan.

Pada zaman dahulu masyarakat mencari informasi melalui televisi, radio, dan surat kabar, dan saat ini mereka sudah menggunakan teknologi dalam memperoleh informasi yang lebih cepat dan praktis. Penggunaan internet dan media sosial sudah menjadi gaya hidup baru pada masyarakat modern. Hal tersebut dapat dilihat pada pola perilaku masyarakat seluruh dunia dalam mengakses informasi, tidak terkecuali generasi muda di Indonesia (Primada \& Ayun, 2015; Panjaitan \& Prasetya, 2017). Generasi muda saat ini tidak bisa lepas dari penggunaan teknologi. Mereka memiliki komunikasi yang terbuka dan cenderung fanatik terhadap media social (Badan Pusat Statisik, 2018). Kegiatan sehari-hari merekapun tidak terlepas dengan teknologi. Sutijono \& Farid, 2018 mengatakan bahwa saat ini segala aktifitas individu dapat dijangkau menggunakan media sosial, seperti facebook, twitter, dan sebagainya. Masyarakat saat ini terutama para generasi milenial sangat menyukai media sosial karena mereka dapat menemukan informasi dan berkomunikasi dengan lebih mudah. Mereka memanfaatkan teknologi untuk melakukan kegiatan sehari-hari seperti berkomunikasi, bertransaksi secara online, mengakses situs pendidikan, bahkan memesan jasa trasnportasi online (Kirana, 2019).

Perkembangan teknologi yang ada telah mempengaruhi segala aspek kehidupan, salah satunya pada layanan bimbingan dan konseling. Kemajuan teknologi informasi dan komunikasi telah memberi pengaruh besar terhadap layanan bimbingan konseling (Hariko, 2017). Seiring dengan perkembangan zaman, konseling tidak lagi dilakukan secara face to face, namun dapat dilakukan melalui jarak jauh menggunakan jaringan internet yang disebut cyber counseling (Ifdil \& Ardi, 2013). Layanan ini mempermudah seseorang yang ingin melakukan konseling namun tidak bisa hadir secara langsung 
(Gibson \& Mitchell, 2008). Adanya layanan tersebut menuntut para konselor dan guru BK untuk menguasai layanan cyber counseling. Para konselor atau guru BK dituntut untuk dapat memberikan layanan bimbingan konseling dengan berbagai cara baru yang kreatif dan inovatif (Aini \& Mudjiran, 2020). Hadirnya layanan cyber counseling di sekolah tentu membuat para siswa merasa terbantu apabila ingin melakukan konseling namun tidak memiliki waktu untuk bertemu guru BK secara langsung. Dengan menggunakan smartphone para siswa sudah dapat melakukan konseling dengan guru BK.

Hadirnya cyber counseling yang diterapkan di sekolah merupakan alternatif pemberian layanan konseling bagi para konselor. Para konselor diharapkan mampu mengembangangkan model konseling dan mengembangkan keterampilan yang dimiliki terutama di bidang IT. Hal ini penting agar para konselor mampu memberikan pelayanan yang terbaik bagi para siswa di sekolah. Pada artikel ini akan membahas mengenai proses penerapan layanan cyber counseling yang diterapkan di sekolah.

\section{METODE PENELITIAN}

\section{Model Penelitian}

Penelitian ini menggunakan metode literature review atau studi kepustakaan. Teknik ini digunakan dengan tujuan mengungkap berbagai teori yang berkaitan dengan masalah yang diteliti sebagai bahan referensi pembahasan hasil penelitian. Metode literature review dilakukan dengan mengumpulkan buku-buku maupun jurnal dari berbagai macam sumber seperti jurnal nasional maupun internasional yang diperoleh dari database google scholar.

\section{Teknik Pengumpulan Data}

Kumpulan data studi literatur pada penelitian ini adalah berupa artikel jurnal yang diperoleh dari database google scholar. Pencarian artikel jurnal yang digunakan terbit pada rentang tahun 2006 sampai tahun 2020. Kata kunci yang digunakan dalam mencari artikel jurnal adalah "layanan cyber counseling", "era global cyber counseling", dan "cyber counseling di sekolah".

\section{Analisis Data}

Analisis jurnal pada studi literatur ini menggunakan metode critical appraisal. Critical appraisal merupakan proses analisis jurnal yang digunakan menjadi landasan teori bagi perbedaan, persamaan dan kekurangan jurnal yang digunakan.

\section{HASIL DAN PEMBAHASAN}

\section{a. Layanan Cyber counseling}

Tahun 1960 dan 1970 merupakan awal dari munculnya layanan cyber counseling yang dilakukan berbasis teks melalui perangkat lunak program Eliza dan Parry (Fadhilah, Susilo \& Rachmawati, 2019). (Corey, 2013) menyebutkan bahwa layanan cyber counseling merupakan proses konseling yang dilakukan oleh seorang konselor profesional kepada konseli. Cyber counseling merupakan suatu konseling yang 
dilakukan ketika konseli dan konselor berkomunikasi secara jarak jauh menggunakan internet (Prasetiawan, 2016).

Semakin berkembangnya teknologi yang sangat pesat, menuntut para konselor untuk mampu mengikuti perkembangan tekonologi saat ini. Oleh karena itu para konselor diharap mampu dalam memberikan layanan bimbingan dan konseling secara online (Sutijono \& Farid, 2018). Layanan cyber counseling dilakukan dengan menggunakan bantuan koneksi internet berupa website, chat, email, dan video conference sehingga konselor dan konseli tidak perlu bertemu secara langsung (Pasmawati, 2016). Bagi konselor di sekolah, konseling ini dinilai efektif karena jika tidak memiliki jadwal pertemuan tatap muka di sekolah, konselor masih dapat memberikan konseling via online (Sutijono \& Farid, 2018).

Konseling menggunakan media sosial seperti whatsapp atau aplikasi lainnya yang dapat menunjang proses konseling tidaklah sulit, karena hampir semua konselor sudah memiliki smartphone dan mampu menggunakan ICT. Selain itu, hampir semua sekolah telah menyediakan website dan laboratorium komputer. Sehingga dalam hal ini para guru BK dapat mengkomunikasikan layanan konseling yang direncanakan kepada pihak sekolah agar dapat terlaksana dengan baik (Kraus, 2011; Hidayah, 2013; Mulyatiningsih, 2015) . Di era globalisasi ini, model layanan cyber counseling sangat dibutuhkan oleh para guru BK karena para siswa tidak terikat jarak dan waktu untuk melakukan konseling dengan guru BK.

\section{b. Urgensi Layanan Cyber counseling di Sekolah}

Para siswa di sekolah merupakan para generasi saat ini yang sangat erat dengan teknologi. Salah satu cara yang dilakukan dengan mengikuti perkembangan teknologi di bidang pendidikan adalah membuat layanan konseling yang efektif dan efisien. Dengan adanya layanan konseling online para siswa akan lebih mudah dalam melakukan konseling dengan guru BK. Hal tersebut tentu dapat meningkatkan keterampilan guru BK dalam menggunakan teknologi dan komunikasi serta berdampak dengan eksistensi layanan bimbingan dan konseling di sekolah (Arista, 2017).

\section{c. Cyber counseling di Sekolah}

Mengikuti perkembangan teknologi yang ada, layanan bimbingan dan konseling juga mengalami perkembangan. Siswa yang ingin melakukan konseling tetapi tidak bisa bertemu secara langsung dengan guru BK dapat menggunakan layanan cyber counseling untuk melakukan konseling. Dinçyürek et al (2012) mengatakan bahwa layanan cyber counseling sangat penting diterapkan di sekolah. Dalam penelitiannya mereka menyebutkan bahwa seorang akademisi menganggap bahwa tidak semua siswa memiliki keberanian untuk datang secara langsung ke layanan konseling yang ada di sekolah. Layanan cyber counseling yang dapat diakses selama 24 jam akan memudahkan siswa melakukan konseling tanpa terbatas waktu.

Saat ini layanan cyber counseling sudah banyak diterapkan di beberapa sekolah di Indonesia. Prahesti (2017) mengatakan bahwa salah satu SMA di Gresik sudah 
menerapkan layanan cyber counseling menggunakan media website. Website merupakan suatu hyperlink yang berisi beragam informasi (Soran, 2014). Alasan diterapkannya layanan tersebut adalah para siswa yang kurang memanfaatkan layanan bimbingan konseling di sekolah dan waktu yang terbatas apabila melakukan konseling di sekolah antara guru BK dengan siswa. Dengan adanya fitur-fitur dalam layanan cyber counseling, guru BK dapat mengatasi permasalahan yang dihadapi oleh siswa.

Selain menggunakan website, layanan cyber counseling dapat dilakukan menggunakan whatsapp. Budianto dan Hidayah (2019) menyebutkan bahwa layanan konseling dapat diberikan melalui whatsapp karena dapat diakses melalui smartphone oleh para siswa. Penggunaan whatsapp sebagai layanan cyber counseling dinilai memudahkan proses konseling antara guru BK dengan siswa. Tidak hanya website dan whatsapp yang dapat digunakan sebagai media dalam layanan cyber counseling. Ada beberapa media yang dapat digunakan seperti video conference, email, chat, dan juga facebook. Salah satu sekolah di Semarang menerapkan layanan bimbingan konseling melalui fecebook. Layanan bimbingan konseling yang dilaksanakan berfokus pada informasi karir kepada para siswanya. Layanan ini dikembangkan karena para siswa yang kurang nyaman ketika harus melakukan konseling secara langsung. Terbukti dengan adanya layanan cyber counseling melalui facebook, para siswa lebih mudah untuk mengetahui informasi karir (Pujiyanti, 2018).

\section{d. Tahap-tahap Cyber counseling}

Cahyo \& Wibowo (2017) menyebutkan ada tiga tahapan dalam proses layanan cyber counseling, yaitu: (1) Tahap persiapan, yang mencakup persiapan hardware (perangkat keras) dan software (perangkat lunak) yang digunakan dalam proses konseling antara konselor dan konseli, (2) Tahap proses layanan bimbingan dan konseling, yaitu pemberian konseling kepada konseli seperti halnya saat bertatap muka. Pelaksanaan cyber counseling menggunakan teknik umum dan teknik khusus. Dalam pelaksanaan cyber counseling ini menekankan pada terselesainya masalah konseli, (3) Tahap akhir, yaitu mengakhiri proses konseling dengan memberikan evaluasi pada keberhasilan konseling dan follow-up. Ada empat kemungkinan yang terjadi pada proses evaluasi, diantaranya: (a) proses konseling sukses ditandai dengan kondisi konseli yang memenuhi effective daily living, (b) konseling dilanjutkan dengan face to face, (c) layanan konseling dilanjutkan pada sesi berikutnya, dan (d) konseli dirujuk kepada konselor lain.

\section{e. Model-model Cyber counseling}

\section{Cyber counseling Melalui Email}

Pedhu (2014) mengatakan salah satu cara inovatif dalam membantu memecahkan masalah konseli yaitu dengan konseling melalui email. Email adalah alat untuk komunikasi berbasis teks yang dapat dilakukan melalui smartphone atau komputer (Pedhu, 2014). Konseling melalui email membantu konseli untuk membahas mengenai permasalahan yang dihadapi tanpa perlu bertemu secara langsung dengan konselor. 
Konseling melalui email memiliki beberapa keunggulan, diantaranya yaitu : (1) kontak konseling dapat dicatat secara permanen yang memudahkan bagi konseli maupun konselor; (2) merumuskan permasalahan dengan mengetik adalah cara efektif; (3) dengan mengetik akan lebih mudah merefleksikan masalah; (4) internet dapat diakses semua kalangan; dan (5) konseli dapat mengirimkan email secara langsung tanpa menunggu sesi konseli selanjutnya (McLeod, 2006).

\section{Cyber counseling Melalui Chat asynchronous}

Konseling melalui chat asynchronous merupakan sistem yang sama seperti email dan text chat yang tidak terikat waktu sehingga konseli dapat mengirimkan pesan kapanpun (Prasetya, 2017). Cyber counseling chatasynchonous dapat diakses melalui smartphone yang dapat dijamin kerahasiannya. Kerahasiaan merupakan salah satu asas dalam pelayanan konseling (Sukardi, 2008). Melalui smartphone layanan cyber counseling chatasynchonous merupakan pelayanan responsif. Pelayanan responsif yaitu memberikan layanan kepada konseli yang membutuhkan bantuan dengan segera agar permasalahannya tidak sampai mengganggu proses perkembangannya (ABKIN, 2008).

\section{Cyber counseling Melalui Teks Menggunakan Riliv Aplikasi Android}

Riliv merupakan aplikasi di smartphone yang menyediakan proses konseling (Apsari et al., 2018). Aplikasi ini dirancang untuk menghubungkan konseli yang ingin menyelesaikan masalahnya melalui konseling secara online. Bantuan psikologi yang diberikan di aplikasi ini dilaksanakan secara profesional oleh para psikolog.

\section{Cyber counseling Melalui Facebook}

Salah satu cara untuk mengembangkan layanan bimbingan konseling adalah dengan memberikan layanan konseling melalui facebook. Cyber counseling melalui facebook dibuat dengan tujuan memberikan solusi bagi seseorang yang kurang nyaman untuk melakukan konseling secara langsung serta terbatas jarak dan waktu (Pujiyanti, 2018). Dengan adanya konseling melalui facebook diharapkan dapat tercapai maanfaat dari layanan bimbingan dan konseling.

Selain itu Ifdil \& Ardi (2013) menyebutkan ada beberapa media yang dapat digunakan dalam melakukan konseling online, diantaranya: (1) video conferencing; (2) Chat, Instant Messaging dan Jejaring Sosial; (3) email; (4) handphone; dan (5) website.

\section{f. Kelemahan Cyber counseling}

Meskipun cyber counseling memiliki banyak kelebihan, namun pada layanan ini juga ditemukan kelemahan atau keterbatasan, antara lain: (a) keberhasilan suatu konseling ditentukan oleh ketersediaan jaringan internet (Haryati, 2020); (b) konselor kesulitan membangun hubungan terapeutik dengan konseli (Shaw \& Shaw, 2006); (c) di Indonesia belum ada hukum yang jelas mengenai layanan konseling online; (d) 
masih banyak konselor yang kurang memiliki keterampilan dalam menggunakan layanan internet; dan (e) sedikitnya penelitian mengenai manfaat konseling online (Bloom, John W., Walz, Garry, 2004).

\section{SIMPULAN}

Berdasarkan pembahasan di atas, dapat disimpulkan bahwa perkembangan teknologi informasi dan komunikasi yang semakin pesat telah menjadi gaya hidup baru bagi masyarakat saat ini. Hal tersebut juga berpengaruh pada bidang pendidikan, yaitu pemberian layanan bimbingan konseling yang dilakukan secara online. Layanan konseling online atau cyber counseling dinilai efektif karena dapat memberikan kemudahan bagi konselor dan para siswa untuk melakukan konseling yang tidak terbatas jarak dan waktu. Adapun media yang dapat digunakan untuk melakukan cyber counseling diantaranya yaitu melalui email, facebook, chat asynchronous, aplikasi riliv, video conference, handphone, dan website.

Dengan adanya layanan konseling online ini, diharapkan para konselor atau guru BK terus meningkatkan kemampuan dalam menggunakan teknologi informasi dan komunikasi agar tetap dapat memberikan pelayananan yang terbaik bagi para siswa.

\section{UCAPAN TERIMAKASIH}

Puji syukur penulis panjatkan kepada Tuhan Yang Maha Esa karena dengan segala berkatNya, Literature Review ini dapat terselesaikan. Pada penulisan ini, penulis banyak mendapat bantuan dari beberapa pihak. Maka dari itu, penulis mengucapkan terimakasih kepada Dr. Abdul Muhid, M.Si selaku dosen pembimbing yang telah membimbing penulis dalam penulisan Literature Review ini. Serta penulis ucapkan terimakasih kepada orang tua dan teman-teman yang telah memberikan dukungan dan motivasi. Semoga dengan adanya Literature Review ini dapat bermanfaat bagi para pembaca.

\section{DAFTAR PUSTAKA}

ABKIN. (2008). Standar Kompetensi Konselor Indonesia. Jakarta: Pengurus Besar ABKIN.

Aini, H., \& Mudjiran, M. (2020). Southeast Asian Journal of Technology and Science Cybercounseling as one of the skills in the guidance and counseling service in the 21 st century Corresponding Author. Southeast Asian Journal of Technology and Science, 1(1), 23-26.

Alexius Endy Budianto, Nur Hidayah, A. A. (2019). Aplikasi Cyber Counseling Dengan Mengoptimalkan Whatsapp Berbasis Komputasi Mobile. 2, 182-193.

Apsari, F. Y., Rama, M. D., dan Prasetyo, E. (2018). Konseling Berbasis Teks Menggunakan Riliv-Aplikasi Android. 5(1), 45-49.

Arista, D. A. dkk. (2017). Aplikasi Cyco (Cybercounseling) Sebagai Salah Satu Alternatif Model Konseling di Sekolah. Seminar Nasional BK FIP-UPGRIS. 230-238.

Badan Pusat Statisik. (2018). Profil Generasi Milenial. Jakarta: KemenPPA.

Bloom, John W., Walz, Garry, R. (2004). Cybercounseling and Cyberlearning an 
Encore. USA: CAPS Press.

Cahyo, N., \& Wibowo, H. (2017). Bimbingan Konseling Online. Jurnal Ilmu Dakwah, 36(2). https://doi.org/10.21580/jid.36i.2.1773

Chaffey, D. (2020). Global social media research summary 2020. https://www.smartinsights.com/social-media-marketing/social-mediastrategy/new-global-social-media-research/

Corey, G. (2013). Teori dan Praktek Konseling dan Psikologi. Bandung: Refika Aditama.

Dinçyürek, S., Cyprus, N., \& Uygarer, G. (2012). Conduct Of Psychological Counseling And Guidance Services Over The Internet: Converging Communications. In TOJET: The Turkish Online Journal of Educational Technology, 11(3).

Fadhilah, S. S., Susilo, A. T., \& Rachmawati, I. (2019). Konseling Daring bagi Mahasiswa. Indonesian Journal of Educational Counseling, 3(3), 283-289.

Gading, I. K. (2020). The Development of Cyber counseling as a Counseling Service Model for High School Students in the Digital Age. 9(2), 301-313. https://doi.org/10.23887/jpi-undiksha.v9i2.25469

Geraijasa. (2019). Praktik Ecomersi pada Lingkup Asean Ditinjau dari Hukum Internasional. https://geraijasa.com/2019/04/27/praktik-e-comerce-padalingkupasean-ditinjau-dari-hukum-international/

Gibson, R.L. \& Mitchell, M. . (2008). Introduction to Counseling and Guidance. New York: Macmillan Publisher.

Hariko, R. (2017). Landasan Filosofis Keterampilan Komunikasi Konseling. Jurnal Kajian Bimbingan Dan Konseling, 2(2), 41-49.

Haryati, A. (2020). Online Counseling Sebagai Alternatif Strategi Konselor dalam Melaksanakan Pelayanan E- Counseling di Era Industri 4 . 0. 2(2), 27-38.

Hidayah, N. dan M. R. (2013). Cyber counseling Kognitif Behavioral di Malang Raya, Jawa Timur. Makalah Tidak Diterbitkan, ada pada penulis.

Ifdil, I., \& Ardi, Z. (2013). Konseling Online Sebagai Salah Satu Bentuk Pelayanan Ekonseling. Jurnal Konseling Dan Pendidikan. 1, 15-21.

Kirana, D. L. (2019). Cyber Counseling Sebagai Salah Satu Model Perkembangan Konseling Bagi Generasi Milenial. Al-Tazkiah: Jurnal Bimbingan dan Konseling Islam, 8(1), 51-63.

Kraus, R. et al. (2011). A Handbook for Mental Health Professionals. India: Elsevier Inc.

McLeod, J. (2006). Pengantar Konseling: Teori dan Studi Kasus. (Diterjemahkan oleh A.

K. Anwar). Jakarta: Kencana Prenada Media Group.

Mulyatiningsih, R. (2015). Konseling melalui Dunia Maya (Cyber counseling). Kompasiana.

Panjaitan, P., \& Prasetya, A. (2017). Pengaruh Social Media Terhadap Produktivitas

Kerja Generasi Millenial (Studi Pada Karyawan PT. Angkasa Pura I Cabang Bandara Internasional Juanda). Jurnal Administrasi Bisnis, 48(1), 173-180. http://administrasibisnis.studentjournal.ub.ac.id/index.php/jab/article/view/1884

Pasmawati, H. (2016). Cyber counseling Sebagai Metode Pengembangan Layanan Konseling Di Era Global. Jurnal Ilmiah Syi'ar, 16(2), 24-54.

Pedhu, Y. (2014). Model konseptual. Psiko Edukasi, 12(2), 78-89. 
94 | Counsellia: Jurnal Bimbingan dan Konseling, Volume 11 (1) 86-94 Mei 2021

Prahesti, Y. (2017). Pengembangan Website Konseling Online Untuk Siswa di Sma Negeri 1 Gresik Yunita Prahesti Bambang Dibyo Wiyono, S . Pd ., M . Pd. Jurnal BK UNESA, 7(3).

Prasetiawan, H. (2016). Cyber counseling Assisted with Facebook Cyber counseling Assisted With Facebook To Reduce Online Game AddICTion. Jurnal Ilmu Pendidikan, Psikologi, Bimbingan Dan Konseling, 6(1), 28-32.

Prasetya, A. F. (2017). Model Cybercounseling: Telaah Konseling Individu Online ChatAsynchronous Berbasis Aplikasi Android. Prosiding Seminar Bimbingan Dan Konseling, 1(1), 31-38. http://pasca.um.ac.id/conferences/index.php/snbk/article/view/204

Primada, O. \& Ayun, Q. (2015). Fenomena Remaja Menggunakan Media Sosial dalam Membentuk Identitas. 3(2).

Pujiyanti, A. (2018). Pengembangan Model Cyber counseling Berbantuan Facebook Untuk Meningkatkan Efektivitas Layanan Informasi Karier Di Sma Negeri 1 Semarang. Prosiding, 22.

Shaw, H. E., \& Shaw, S. F. (2006). Critical Ethical Issues in Online Counseling: Assessing Current Practices With an Ethical Intent Checklist. Journal of Counseling \& Development, 84(1), 41-53. https://doi.org/10.1002/j.15566678.2006.tb00378.x

Soran. (2014). Mengetahui Pengertian Website Dan Jenisnya - Pengertian Apapun. http://www.pengertianku.net/2014/09/mengetahui-pengertian-website-danjenisnya.html

Sukardi, D. K. (2008). Pengantar Pelaksanaan Program BK di Sekolah. Jakarta: Rineka Cipta.

Sutijono, S., \& Farid, D. A. M. (2018). Cyber counseling di Era Generasi Milenial. Sosiohumanika, 11(1), 23. 